Article

\title{
The Successful Adoption of IS in the Tourism Public Sector: The Mediating Effect of Employees' Trust
}

\author{
Marwa Ghanem ${ }^{1, * \mathbb{D}}$, Ibrahim Elshaer ${ }^{2,3} \mathbb{1}$ and Alaa Shaker ${ }^{4,5}$ \\ 1 Tourism Studies Department, Faculty of Tourism and Hotels, Suez Canal University, 41522 Ismailia, Egypt \\ 2 Department of Management, School of Business, King Faisal University, 380 Al-Ahsaa, Saudi Arabia; \\ Ielshaer@kfu.edu.sa \\ 3 Hotel Studies Department, Faculty of Tourism and Hotels, Suez Canal University, 41522 Ismailia, Egypt \\ 4 Department of Tourism and Hospitality, Arts College, King Faisal University, 380 Al-Ahsaa, Saudi Arabia; \\ aazazz@kfu.edu.sa \\ 5 Faculty of Tourism and Hotels, Suez Canal University, 41522 Ismailia, Egypt \\ * Correspondence: marwamagdy00@gmail.com
}

Received: 18 April 2020; Accepted: 6 May 2020; Published: 9 May 2020

\begin{abstract}
There have been many attempts to understand the role of trust in the success of Information Systems (IS), but they have mainly studied users' trust in IS themselves in online contexts, with little attention being paid to other possible trust types and organizational IS contexts. Also, there is a dearth of research on the topic in relation to tourism context and developing countries in general. This study examines the mediating role of three types of trust (management-based, provider-based, and system-based trust) in the relationship between tourism IS qualities (system, information, and service quality) with employees' satisfaction and the intention to and actual use of a system. Perceptions were tested with data from 200 employees in the public sector of the Egyptian tourism industry using structural equation modeling. The results revealed that trust directly affects intention to use/use and user satisfaction, and it completely mediates the effect of the IS qualities on the intention to use/use and user satisfaction. This study draws attention to the requirement of investigating different types of trust to better understand its impact on tourism IS adaptation in developing countries.
\end{abstract}

Keywords: tourism public sector; trust; IS provider; senior management; IS success theory; satisfaction; intention to use

\section{Introduction}

Information systems (IS) adoption plays a critical role in the improvement of the operational effectiveness and efficiency of organizations. This is quintessentially achieved through advancing information structure and organizational capabilities, cutting costs and delivery time, enhancing customer service quality, and promoting innovation generally [1]. This, in turn, would lead to enhancing decision-making processes within organizations. Against this background, IS adoption helps organizations bolster their economic sustainability and develop a sustainable competitive advantage [2]. This explains why tourism organizations invest much effort, and money to adopt IS. In the same vein, it is critical for managers to understand the factors and barriers that influence the effectiveness of IS implementation. Researchers have agreed that the success of IS is a complex and multi-factorial subject [3-5], affected by contextual aspects [6-8]). This has led to the identification of many factors that constitute and influence the success of IS. Due to the increasing complication of technology and the uncertainty and risk perceptions tied to the development of IS $[9,10]$, trust has emerged as one of the IS success influences since the late 1990s [11], and it is still attracting scholars' attention from different disciplines. 
In the tourism literature, trust has also been identified as a critical determinant of IS usage in the context of online travel purchase [12-14], mobile-tourism [15,16], and web-based tourism IS [6,17], with little attention being paid to the organizational trust and whether employees' perspectives of trust affect the success of tourism IS adoption. Other research gaps related to the influence of different types of trust in changed IS contexts (e.g., web-based vs. organizational and public vs. private IS, and developing vs. developed country contexts) have been identified in tourism and IS research.

First, the great majority of trust studies in tourism $[6,13,14,17])$ and the IS $[7,16,18,19]$ fields were mainly conducted in the context of web-based IS. These studies investigated online customers' perspectives, where usage is usually voluntarily by default [20], while little is known about the impact of trust on organizational IS success, either in the public or private sectors, and even fewer IS researchers have explored trust from the employees' perspectives e.g., [20,21]. Although online and offline IS have many commonalities, they may differ in aspects, such as the impersonal nature of the internet, the degree of contextual uncertainty, the mandatory and optional usage of IS, and the physical and temporal separation between the trustee (IS provider) and user (customers or employees) [7,22]. This raises questions about whether the influence of trust on IS success differs between online and offline systems, warranting deeper investigation of organizational IS usage and the role of employees' trust in its success.

Second, while some researchers have drawn attention to the need to diversify the types of trust examined in the study of IS's successful adoption, most previous trust studies focused on the relationship between the user and the IS themselves $[23,24]$. Other types of trust that might drive IS success from the users' perspectives have received less attention, e.g., institutional trust [9], provider trust [25,26], and management, co-workers, and work-group trust [27]. These types of trust are conceptually and empirically distinct [28], and thus may vary in their impacts on successful IS adoption. Thus, Söllner et al. [24] suggested the adoption of an approach taking multiple types of trust into account while studying IS implementation. In this connection, the current study examined the mediating role of three distinct types of trust in the relationship between IS success factors-management-based, provider-based, and system-based trust. The selectivity of these trust types has been based on the fact that besides the system itself, the senior managers and IS providers are the first parties that the employees usually encounter in their first stage of IS usage. It follows that such types would most likely influence the effective implementation of the IS. Another reason why such types are selected is the dearth of research that examines the influence of management and provider-based trust on IS usage in developing countries, particularly in the context of the public tourism sector.

Evidence on the role of trust in tourism (e.g., [14,17,29]) and IS $[9,21,24,30,31]$ research is derived mainly from cases applied in developed countries. To the researchers' knowledge, a number of tourism and IS studies have explored trust in the developing countries, with the following notable exceptions;-Koo and Wati [19], Joubert and Van Belle [32], Abdal-Fadeel [6], and Ayyash et al. [33]. However, the former two articles examined the role of customers' trust in adopting mobile banking/e-commerce, while the later examined web-based IS, and none of them explored employees' perspectives or were applied in organizational IS contexts, which is why this study targets this particular area of research. Developed and developing countries vary in socio-economic and cultural aspects [6,19]. Moreover, trust has been recognized as a situational construct, which drove Abdul-Rahman and Hailes [23] and Cyr [18] to state that the way trust is built and the types of trust that should be considered as phenomena can differ across different contexts. Consequently, the applicability of prior results regarding the influence of trust in the success of tourism IS adopted in developing country and public sector contexts is questionable. This suggests that further insights are needed to investigate cases from less-developed economies as well as developed ones.

With the above in mind, the current study sets out to answer the following question: what is the role of employees' trust in the successful adoption and implementation of ISs in tourism public sector organizations? Three types of trust (management-based, provider-based, and system-based trust) have been investigated from the perspectives of the public sector employees. The objectives of this study 
are: 1) to assess the potential effects of IS qualities on employees' trust.; 2) to examine the relationship between employees' trust, and their satisfaction and intention to use/use the IS; 3 ) to investigate the mediating effect of trust between IS success factors in the tourism business.

\section{Theoretical Foundation and Hypothesis Formulation}

\subsection{Conceptualization of Trust}

Although trust has been studied in a variety of disciplines (including social psychology, organizational behavior, marketing, and IS), it remains difficult to conceptualize, due to its changing, evolving, and multi-faceted nature [7,13,34]. Among the many attempts of prior studies to define trust, the integrated model of organizational trust created by Mayer, Davis and Schoorman [35] has gained widespread acceptance among researchers [36-38], and it was described as a turning point in trust conceptualization [37]. As of 2019, it has been cited over 19,500 times (Google Scholar, 2019). Mayer et al. [35] integrated the work of scholars from different disciplines including management, economics, psychology, sociology, and philosophy to conceptualize trust, which they perceived as a multidimensional concept, defined as "the willingness of a party to be vulnerable to the actions of another party based on the expectation that the other will perform a particular action important to the trustor, irrespective of the ability to monitor or control that other party" [35] (pp. 712).

In their integrative model of organizational trust, Mayer et al. [35] identified ability, benevolence, and integrity as the three characteristics of a trustee to generate trustworthiness. Ability means that trustors believe that trustees have the power to do for them what they need to be done. Benevolence is the level to which trustees are supposed to want to do good to trustors, aside from egocentric profit motives. Integrity indicates that trustors believe that trustees make good-faith agreements, tell the truth, act ethically, and fulfill promises [27,36]. Accordingly, Ability, benevolence, and integrity were adopted to examine trust aspects in this study.

\subsection{IS Success Theory}

The DeLone and McLean [39] model of IS success was employed in this study to investigate the mediating role of trust. The model is recognized as a major contribution to IS success research and has been accepted by various studies from different disciplines $[8,40,41]$. However, only a few studies have employed the model in tourism research and mainly examined either travelers' electronic word of mouth [42], mobile-tourism [15,16], or web-based tourism systems [6,43,44]. Although tourist organizations invest a huge amount of money and effort in IS implementation, and that researchers [3] asserted the high rate of IS failure than success, especially in developing countries [6,33], no study has adopted the IS success model to understand employees' views of organizational IS adoption in public or private tourist companies. DeLone and McLean [39] stated that IS qualities dimensions (information quality, service quality, and system quality) influence use and satisfaction, which, in turn, leads to certain net benefits. Although not included in their model, trust is argued to be an important driver of successful IS adoption in tourism $[6,12,13,17]$.

\subsection{IS Qualities and Trust}

The positive impact of IS qualities (information, system, and service quality) on users' trust has been supported in several previous tourism e.g., $[12,14,17]$ and e-commerce e.g., [36,40] studies. For instance, Filieri [17] and Ponte et al. [13] found that provisions of relevant and quality information on tourist websites could stimulate consumers' perceived trustworthiness. While Wang et al. [14] studied hotel websites and recognized website quality as a key driver to customer's trust in the e-commerce field, Brown and Jayakody [40] and Keen et al. [45] found that the service quality provided by the system also affects users' willingness to trust IS. Such empirical findings are equally applicable to organizational tourism IS-if employees perceived IS to be high-quality, they would trust the system [20] and perceive IS providers and senior managers as trustworthy, competent and 
skilled (ability), possessing positive intentions to provide support (benevolence), and make good-faith agreements and fulfill promises (integrity). Therefore, this study hypothesizes that (Figure 1):

H1a: IS qualities have a positive, significant impact on senior management-based trust

H1b: IS qualities have a positive, significant impact on system-based trust

H1c: IS qualities have a positive, significant impact on provider-based trust

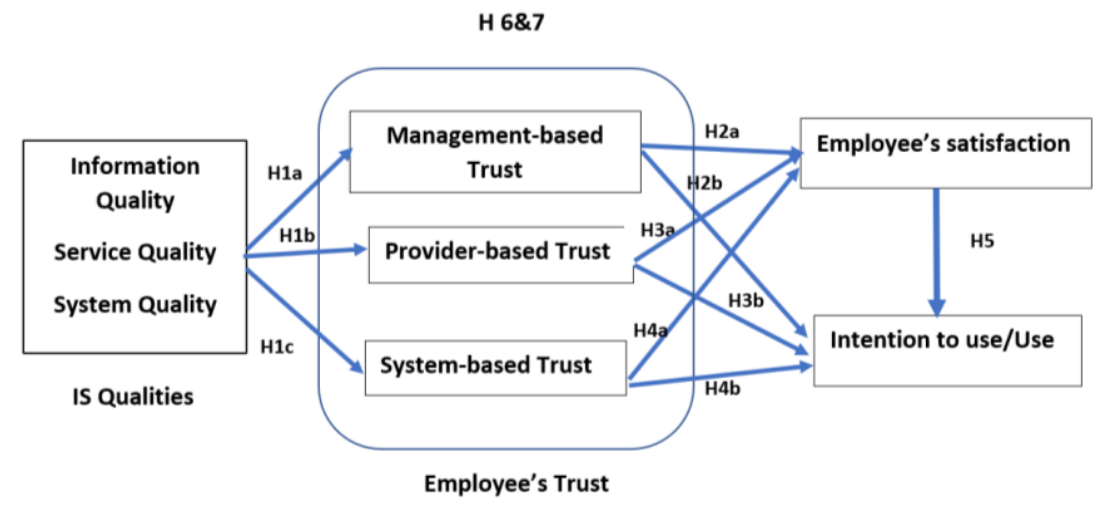

Figure 1. Research framework and hypotheses.

\subsection{Trust and Satisfaction}

User satisfaction has been recognized as a key determinant of IS success [5]. Prior research seeking to identify what initiates user satisfaction noted the crucial role of trust $[6,8,19,46]$. Chung and Kwon [47] referred to satisfaction as a consequence of trust, and Abdal-Fadeel [6] argued that systems not perceived as trustworthy have lower user satisfaction levels, which subsequently hinders successful adoption. Moreover, Huntington et al. [48] found that trust towards a system owner, besides trusting the system itself, influences the overall satisfaction of users.

In organizational contexts, researchers found that high management support significantly influences user satisfaction with the system [49,50], and added that satisfaction among hotel employees could be improved by enhancing their perceptions of organizational trust [34]. Hung et al. [25], on the other hand, indicated the importance of the knowledge, quality, and support providers deliver to users in IS success. Accordingly, we posit that employees' trust in the qualities of IS in addition to their trust in the provider and management support and abilities encourage their satisfaction towards the system, which consequently increases the possibilities of successful IS adoption (Figure 1).

H2a: Senior management-based trust has a positive, significant impact on user satisfaction

H3a: System-based trust has a positive, significant impact on user satisfaction

H4a: Provider-based trust has a positive, significant impact on user satisfaction

\subsection{Trust and Intention to Use/Use}

In tourism and e-commerce fields, several empirical studies have confirmed that the customers' intention to use a system is affected by the level of trust they hold towards that system $[8,30]$. Masri et al. [12] and Ponte et al. [13] and Wang et al. [14], For instance, indicated that the greater the consumers' trust in travel websites, the higher their intention to use them. Also, Thielsch et al. [20] (pp. 2), who studied organizational context, argued that "if employees trust an IS, they will probably use it; if they distrust an IS, they will probably try to find ways to avoid it".

Although agreed on the significant influence of system-based trust on IS use, prior studies provided contradictory results regarding the influence of provider and institutional trust. For instance, 
Van Slyke et al. [31], who studied mobile-commerce adoption in South Africa, found that although system-based trust affects the intention to use, none of the providers or institutional trust types did. In contrast, other prior results on developed countries provided evidence that lacking trust in online [31] and organizational IS providers [26], in addition to institutional trust [51], often leads to customers' unwillingness to use systems. Such contradictory results call for further examination of the role of the context, to better understand the influence of trust on system use.

Accordingly, in the context of the public tourism sector, we hypothesize that if employees trust that the system is high-quality and provides reliable information, and if they perceive that the IS provider and senior management are trustworthy, employees will likely continue using IS, thus increasing probabilities for system success:

H2b: Senior management-based trust has a positive, significant impact on intention to use/use

H3b: System-based trust has a positive, significant impact on intention to use/use

H4b: Provider-based trust has a positive, significant impact on intention to use/use

\subsection{Satisfaction and Intention to Use/Use}

User satisfaction and IS usage have long been considered as signs of IS success [5,39]. The theory of IS success [39] states that improved satisfaction causes a higher intention to use, which consequently affects the actual use, and thus, the success of IS. In line, tourism studies have provided strong evidence to confirm the positive correlation between user's satisfaction and their intention to use IS. For instance, Chung et al. [43] asserted that customers recognition of the usefulness of a certain tourist website and their satisfaction with it derived good behavior intention to use the system. Similar tourism e-commerce studies by Abdal-Fadeel [6], Filieri et al. [44] and Hew et al. [15] further support the theoretical relationship between satisfaction and IS use; therefore:

H5: User satisfaction has a positive, significant impact on intention to use/use

\subsection{The Mediating Effect of Trust}

In tourism studies, trust was found to be a crucial factor in user satisfaction $[6,34]$ and intention to use/use $[13,14,17,29]$. Studies also identified that IS qualities aspects are essential in trust-building $[14,20]$. Therefore, in the tourism and e-commerce fields, Wang et al. [14] showed that hotel website quality is a strong predictor of customer's trust and found the mediating role of trust between website quality and consumers' online booking intentions. In relation, Koo and Wati [19] examined IS trust in the mobile-commerce context and found that trust fully mediates the relationship between information quality and user satisfaction, and partially mediates the relationship between system quality and user satisfaction.

In accordance, this study anticipated that in the organizational tourism IS context, trust mediates the effects of IS qualities on employees' satisfaction and intention to use/use IS. It is argued that if employees perceived a system to be of high-quality (in terms of information, system, and service quality), they would assume that the system is beneficial and would trust it [20]. Trust would also be positively influenced when the IS provider and senior management are capable, fulfill their promises regarding the system, and are willing to support employees. In turn, such trusting beliefs increase employees' satisfaction [6] and intention to use/use [51] (Figure 1):

H6: Management-based trust, System-based trust, and Provider-based trust mediate the relationship between IS qualities and user satisfaction

H7: Management-based trust, System-based trust, and Provider-based trust mediate the relationship between IS qualities and intention to use/use 


\section{Research Methods}

\subsection{Instrument Design and Sample}

A questionnaire survey was used to test the research hypotheses. Previously validated scales were adapted and modified to suit the public tourism sector setting examined in this study (See Appendix A). As noted by the creators of the IS success model adopted in this study, "selection of dimensions and measures should be contingent on the objectives and the context of the empirical investigation, but tested and proven measures should be used whenever possible. Completely new and untested metrics should be adopted only as a last resort" [52] (pp. 43).

A ten-point continuous scale from 0 to 10 was used to measure the study indicators, in which 0 equals completely disagree, and 10 equals completely agree with sentences. The instrument was developed in English and translated into Arabic (the official language of Egypt). A professional translator reviewed the questions to ensure matching terms in English and Arabic. A pilot-test was then conducted with five employees in the Egyptian Ministry of Tourism to ensure the validity and consistency of the survey.

Data were collected from employees in governmental tourism authorities in Egypt (i.e., the Egyptian Ministry of Tourism, the Egyptian Tourism Authority, and the Tourism Development Authority). Managerial IS users were excluded from the sample set because participants were asked to rate their perceptions on management-based trust. We obtained data from a survey of 300 employees using the drop and collect method during March and April of 2018. The participants from each authority ranged from 90 to 110, to avoid the under- or over-representation of certain authorities. A total of 210 responses were obtained. Ten questionnaires were excluded due to incomplete data, leaving 200 usable forms (a response rate of around 66.6\%).

\subsection{Demographic Characteristics}

Respondents' gender distribution indicated that $36.5 \%$ were males (73), and $63.5 \%$ were females (127). The age distribution showed that $32.5 \%$ (65) were 25 to 30 years old, $27.5 \%$ (55) were 31 to 40 years old, 34\% (68) were 41 to 50 years old, and 6\% (12) were 51 years old and above. The education distribution of respondents showed that $82.5 \%$ (165) were graduates, while $16.5 \%$ (33) held postgraduate degrees, and $11 \%$ (22) were conducting postgraduate studies.

\subsection{Data Analysis Technique}

Numerous data analysis techniques were used to analyze the study data, as described below:

1. Descriptive statistics analyses, consisting of mean, median, and mode (central tendency measures), standard deviation (SD) (dispersion) measures), and the distribution of scores (skewness) [53].

2. Confirmatory factor analysis (CFA) was employed to test convergent and discriminant validity.

3. Structural equation modeling (SEM) was conducted to investigate the causal relationship between the study variables. SEM is one of the best techniques that can permit complete and simultaneous analysis of all relationships in multidimensional and complex phenomena [54].

To test the structural model's goodness of model fit (GOF), we employed the following:

a. Measures of absolute fit ( $\chi 2 / \mathrm{df}$ and RMSEA)

b. Measures of incremental fit (CFI and NFI)

c. Measures of parsimony fit (PCFI and PNFI) $[55,56]$

\section{Results}

All conditions necessary for the application of CFA and SEM (such as missing data treatments, sample size adequacy, and dealing with outliers) were achieved as described in this section. The current research sample size of 200 was adequate for SEM for the following reasons - $t$ fulfilled Nunnally's [57] requirements of at least ten answers per item (the model has 20 indicators; therefore, the required 
sample size should be 200). It was also consistent with Boomsma's [58] suggestion that the sample size should be based on the ratio of variables ( $\mathrm{p}$ ) to unobserved (latent) variables $(\mathrm{k})$. The ratio in this study was equal to 3.33 (20 indicators/six constructs); thus, a sample size of at least 200 participants was required, consistent with Hair et al.'s [56] requirement of at least 100-150 to have stable maximum likelihood estimation (MLE) solutions. We examined data for missing values utilizing the SPSS package and identified lots of missing values randomly occurring in 10 out of 220 questionnaires $(<5 \%)$; thus, we eliminated these questionnaires as they could cause a dramatic negative impact on the research results [56]. Finally, using SPSS boxplot, no outliers were detected.

\subsection{Common Method Variance}

This study considered the treatment and analysis of common method variance (CMV) because the data were obtained using a self-reported questionnaire [59]. In the questionnaire design process, the study conducted several procedures to minimize CMV [60]. The questionnaire was designed such that the dependent variables precede the independent variable [61]. In answering the questionnaire, respondents were guaranteed their anonymity and confidentiality. The Harman single factor test was finally tested to examine CMV, where all dependent and independent indicators are submitted in SPSS for exploratory factor analysis (EFA), and the extracted factors are constrained to the value of 1 without rotation. Accordingly, only one dimension has been extracted to predict $41.5 \%$ of the variance, which gives evidence that this factor does not explain much of the variance, so CMV is not an issue in this study [60].

\subsection{Descriptive Analysis Results}

The descriptive analysis results are shown in Table 1, displaying information regarding the mean, median, mode, SD, and skewness values of the current study data. It can be seen that the mean values of the trust dimensions (provider-based trust, senior management-based trust, and system-based trust) are between 4.91 to 6.27 , indicating that employees have a moderate tendency to agree with the variables that measure trust dimensions. However, they have a moderate/strong tendency (with mean values of 5.85 to 8.08 ) to agree with the variables that measure the quality of the system they used (system quality, service quality dimensions, and information quality). Similarly, the descriptive statistics evince that the employees tend to agree (with mean values of 5.20 to 7.73 ) with the variables that measure intention to use/use and satisfaction dimensions.

Table 1. Descriptive analysis results.

\begin{tabular}{ccccccc}
\hline Variables & & Mean & Median & Mode & SD & Skewness \\
\hline \multirow{3}{*}{ Provider-based trust } & PROV.1 & 6.24 & 6 & 7 & 1.83 & -0.04 \\
& PROV.2 & 6.13 & 6 & 7 & 1.88 & -0.14 \\
& PROV.3 & 6.27 & 7 & 7 & 1.90 & -0.34 \\
& TM.1 & 5.65 & 6 & 7 & 1.74 & -0.28 \\
Management-based trust & TM.2 & 5.49 & 6 & 7 & 1.81 & -0.42 \\
& TM.3 & 5.42 & 5 & 7 & 1.75 & -0.06 \\
& TM.4 & 5.42 & 6 & 7 & 1.64 & -0.29 \\
System-based trust & TM.5 & 5.53 & 6 & 7 & 1.89 & -0.34 \\
& T.sys.1 & 4.91 & 5 & 3 & 1.95 & 0.34 \\
& T.sys.2 & 4.92 & 5 & 5 & 2.14 & 0.12 \\
System quality (SYS.1) & T.sys.3 & 4.94 & 5 & 5 & 1.83 & 0.18 \\
& Systemquality1 & 7.51 & 8 & 9 & 1.96 & -0.79 \\
& Systemquality2 & 7.80 & 8 & 8 & 1.92 & -0.74 \\
Information quality (SYS.2 & Systemquality3 & 7.57 & 8 & 8 & 1.98 & -0.85 \\
& Informationquality1 & 7.62 & 8 & 8 & 1.72 & -0.68 \\
& Informationquality2 & 8.01 & 8 & 10 & 1.81 & -0.92 \\
& Informationquality3 & 7.51 & 8 & 9 & 1.95 & -0.75 \\
\hline
\end{tabular}


Table 1. Cont.

\begin{tabular}{ccccccc}
\hline Variables & & Mean & Median & Mode & SD & Skewness \\
\hline & Servicequality1 & 6.03 & 6 & 5 & 1.56 & -0.71 \\
& Servicequality2 & 7.07 & 7 & 8 & 1.81 & -0.72 \\
Service quality (SYS.3) & Servicequality3 & 6.35 & 7 & 6 & 1.55 & -0.76 \\
& Servicequality4 & 6.65 & 7 & 8 & 1.55 & -0.78 \\
& Servicequality5 & 5.85 & 8 & 6 & 1.90 & -0.72 \\
User satisfaction & Satis.1 & 5.48 & 6 & 5 & 2.30 & 1.35 \\
& Satis.2 & 5.20 & 5 & 5 & 2.10 & 1.55 \\
& Satis.3 & 6.12 & 6 & 5 & 1.99 & 0.67 \\
Intention to use/use & Use.1 & 5.62 & 6 & 5 & 2.02 & -0.07 \\
& Use.2 & 7.73 & 7 & 6 & 2.00 & -0.15 \\
& Use.3 & 6.74 & 6 & 5 & 2.11 & -0.79 \\
\hline
\end{tabular}

Note: SD = Standard deviation; scale from 0 to 10 was employed to measure the study variables where 0 means completely disagree with this statement, and 10 means completely agree.

The descriptive statistics in Table 1 show that all standard deviation values are between 1.55 and 2.11 , indicating that the data are normally distributed. Additionally, Table 1 has some information regarding the distribution of scores (skewness). Some skewness values are positive and close to zero, showing a minor skew to the left side, while some skewness values are negative and close to zero, which shows a minor skew to the right side.

\subsection{Test of Validity and Reliability}

A first-order confirmatory factor analysis (CFA) model (Figure 2) was employed to test and analyze the convergent and discriminant validity of the study constructs. It showed acceptable goodness of fit at X2 $(155, N=200)=349.741, P=0.000, \mathrm{CMIN} / \mathrm{df}=2.25, \mathrm{CFI}=0.958, \mathrm{NFI}=0.928, \mathrm{IFI}=0.949$, PCFI $=0.757$, PNFI $=782$, RMSEA $=0.07$. Additionally, data in Table 2 approves the convergent validity of the research scales, as all loadings are satisfactorily high and significant at $P<0.001$; the average variance extracted (AVE) surpasses the value of 0.50 for all dimensions, as suggested by Hair et al. [56]; and the composite reliability for all dimensions are between 0.877 and 0.963 , above the threshold of 0.8 which shows that the heterogeneous variables that supposed to measure each of the study factors have an overall acceptable and satisfactory reliability [56]. Overall, the convergent validity results approve that the measures of the current study constructs that are supposed to be theoretically related are indeed actually related. Table 2 also shows that the values of the maximum shared variance (MSV) are lower than the values of the average variance extracted (AVE), and the square root of AVE is greater than the inter-construct correlations, which indicates good discriminant validity for the study constructs [56].

Table 2. Convergent and discriminant validity of the study constructs.

\begin{tabular}{ccccccccc}
\hline & CR & AVE & MSV & $\begin{array}{c}\text { System } \\
\text { Trust }\end{array}$ & $\begin{array}{c}\text { System } \\
\text { Quality }\end{array}$ & $\begin{array}{c}\text { User } \\
\text { Satisfaction }\end{array}$ & $\begin{array}{c}\text { Intention } \\
\text { to Use }\end{array}$ & $\begin{array}{c}\text { Top } \\
\text { Management } \\
\text { Trust }\end{array}$ \\
\hline System trust & 0.963 & 0.897 & 0.785 & 0.947 & & & & \\
Provider \\
Trust
\end{tabular}

Note: CR = Composite Reliability; AVE = Average Variance Extracted; MSV = Maximum Shared Variance. 


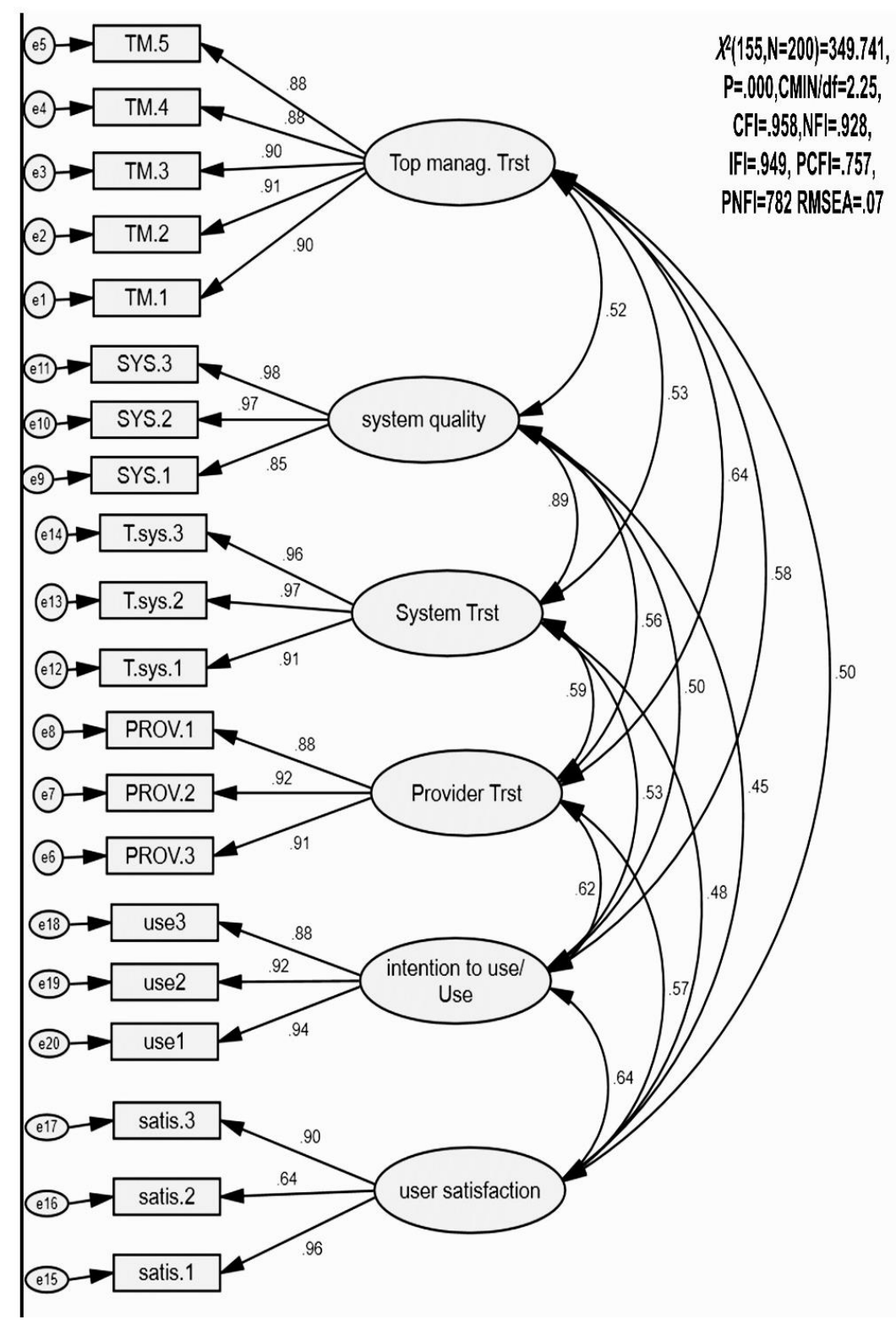

Figure 2. First order confirmatory factor analysis model.

\subsection{Structural Equation Modeling Results}

For the purpose of the current study's objective of investigating the mediating role of trust (senior management, provider-based, and system-based trust) in the relationship between system quality with intention to use/use and user satisfaction, the study executed a partial aggregation procedure [62] on the system quality construct (comprising three dimensions-system quality, service quality, and information quality), whereby a composite average score for every single dimension was calculated to form three variables, named SYS.1, SYS.2, and SYS.3. We employed this factor (system quality) as a partial aggregation and drew it in a second-order manner, as recommended by Bagozzi and Heatherton [62].

Table 2 presents the goodness of fit indices of the structural model. It can be seen that it shows an acceptable fit to the data $(\mathrm{x} 2 / \mathrm{df}=1.371, \mathrm{CFI}=0.986, \mathrm{NFI}=0.950, \mathrm{IFI}=0.983, \mathrm{PNFI}=0.880, \mathrm{PCFI}=0.830$, and RMSEA $=0.043$ ) (see Table 3). The SEM results evince support for the current study hypotheses, indicating the mediating role of trust (senior management-based, provider-based, and system-based trust) in the causal relationship between system quality with intention to use/use and user satisfaction. 
Table 3. Goodness of fit indices.

\begin{tabular}{|c|c|c|}
\hline GOF Statistics & Obtained Value & Reference Value \\
\hline $\begin{array}{c}x^{2} / \mathrm{df} \\
\text { Chi-square/degree of freedom }\end{array}$ & $\begin{array}{c}219.398 / 160 \\
(1.371)\end{array}$ & $<3.00$ \\
\hline $\begin{array}{c}\text { CFI } \\
\text { comparative fit index }\end{array}$ & 0.986 & $\mathrm{CFI} \geq 0.9$ \\
\hline $\begin{array}{c}\text { NFI } \\
\text { Normed fit index }\end{array}$ & 0.950 & $\mathrm{NFI} \geq 0.9$ \\
\hline $\begin{array}{c}\text { IFI } \\
\text { Incremental fit index }\end{array}$ & 0.983 & IFI $\geq 0.9$ \\
\hline $\begin{array}{c}\text { PNFI } \\
\text { Parsimony normed fit index }\end{array}$ & 0.800 & $\mathrm{PNFI} \geq 0.50$ \\
\hline $\begin{array}{c}\text { PCFI } \\
\text { Parsimony comparative fit index }\end{array}$ & 0.830 & PCFI $\geq 0.50$ \\
\hline $\begin{array}{c}\text { RMSEA } \\
\text { Root mean square error of approximation }\end{array}$ & 0.043 & RMSEA $\leq 0.05$ \\
\hline
\end{tabular}

After gaining satisfactory GOF for the model, hypotheses were investigated and tested (see Figure 3 and Table 4). According to the conceptual model, we tested ten hypotheses representing the suggested relationships among research variables, as shown in Figure 1 and Table 4 .

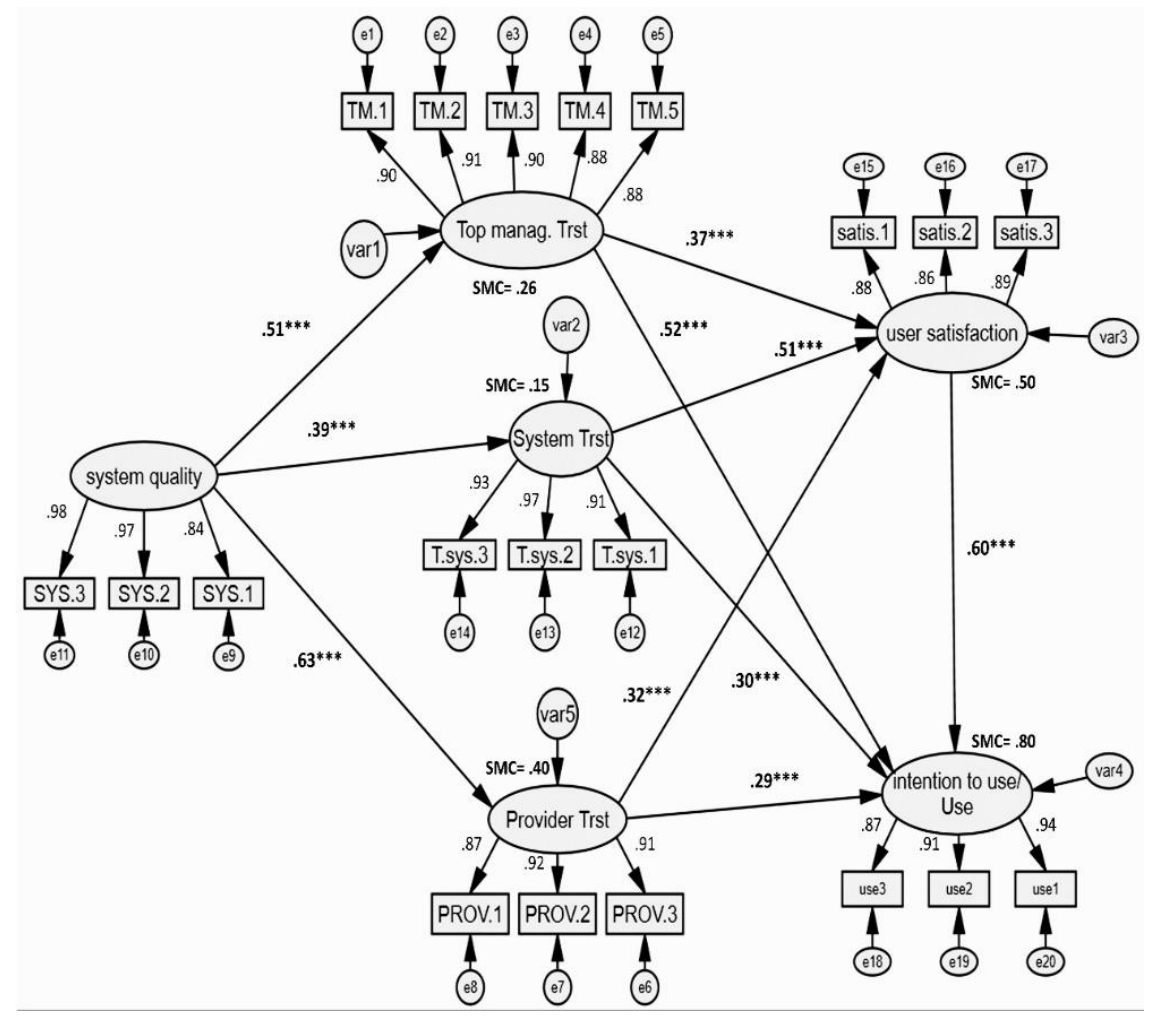

Figure 3. Proposed measurement and structural model.System quality: Information System Qualities; Top Manag. Trst: Senior Management-based Trust; System Trst: System-based Trust; Provider Trst: Provider-based Trust; SMC: Squared Multiple Correlation; ${ }^{* * *}$ : Correlation is significant at the 0.001 level. 
Table 4. Standardized and unstandardized Path coefficients, standard error, critical ratio, $P$-value, and explanatory power.

\begin{tabular}{|c|c|c|c|c|c|c|c|c|c|}
\hline & Hypotheses & $\begin{array}{l}\text { UN Standardized } \\
\text { Regression } \\
\text { Weights }\end{array}$ & $\begin{array}{c}\text { Standardized } \\
\text { Regression } \\
\text { Weights }\end{array}$ & $\begin{array}{l}\text { Standard } \\
\text { Error }\end{array}$ & $\begin{array}{l}\text { Critical Ratio } \\
\text { (C.R.) }\end{array}$ & "P" Value & Total Effects & SMC & $\begin{array}{c}\text { Hypotheses } \\
\text { Results }\end{array}$ \\
\hline H1a & IS qualities $\rightarrow$ Senior Manag. Trst & 0.508 & 0.51 & 0.070 & 7.224 & $* * *$ & - & - & Supported \\
\hline $\mathrm{H} 1 \mathrm{~b}$ & IS qualities $\rightarrow$ System Trst & 0.360 & 0.39 & 0.065 & 5.538 & $* * *$ & - & - & Supported \\
\hline $\mathrm{H} 2 \mathrm{a}$ & IS qualities $\rightarrow$ Provider Trst & 0.696 & 0.63 & 0.077 & 8.982 & $* * *$ & - & - & Supported \\
\hline $\mathrm{H} 2 \mathrm{a}$ & Senior Manag. Trst $\rightarrow$ User Satisfaction & 0.366 & 0.37 & 0.053 & 6.950 & $* * *$ & - & - & Supported \\
\hline $\mathrm{H} 2 \mathrm{~b}$ & Senior Manag. Trst $\rightarrow$ Intention to Use/Use & 0.540 & 0.52 & 0.079 & 6.835 & $* * *$ & - & - & Supported \\
\hline H3a & System Trst $\rightarrow$ User Satisfaction & 0.560 & 0.51 & 0.093 & 6.021 & $* * *$ & - & - & Supported \\
\hline $\mathrm{H} 3 \mathrm{~b}$ & System Trst $\cdots$ Intention to Use/Use & 0.320 & 0.30 & 0.091 & 3.516 & $* * *$ & - & - & Supported \\
\hline $\mathrm{H} 4 \mathrm{a}$ & Provider Trst $\rightarrow$ User Satisfaction & 0.330 & 0.32 & 0.087 & 3.793 & $* * *$ & - & - & Supported \\
\hline $\mathrm{H} 4 \mathrm{~b}$ & Provider Trst $\rightarrow$ Intention to Use/Use & 0.310 & 0.29 & 0.078 & 3.974 & $* * *$ & - & - & Supported \\
\hline H5 & Intention to Use/Use $\rightarrow$ User Satisfaction & 0.640 & 0.60 & 0.126 & 5.079 & $* * *$ & - & - & Supported \\
\hline H6 & $\begin{array}{l}\text { IS qualities } \rightarrow \rightarrow \text { Senior Manag. Trst, System Trst, and } \\
\text { Provider Trst } \rightarrow \rightarrow \text { User Satisfaction }\end{array}$ & - & - & - & - & - & $0.53^{* * *}$ & - & Supported \\
\hline \multirow[t]{6}{*}{ H7 } & $\begin{array}{c}\text { IS qualities } \rightarrow \rightarrow \text { Senior Manag. Trst, System Trst, and } \\
\text { Provider Trst } \rightarrow \rightarrow \text { Intention to Use/Use }\end{array}$ & - & - & - & - & - & $0.63^{* * *}$ & - & Supported \\
\hline & Senior Manag. Trst & - & - & - & - & - & - & 0.26 & - \\
\hline & System Trst & - & - & - & - & - & - & 0.15 & - \\
\hline & Provider Trst & - & - & - & - & - & - & 0.40 & - \\
\hline & User Satisfaction & - & - & - & - & - & - & 0.50 & - \\
\hline & Intention to Use/Use & - & - & - & - & - & - & 0.80 & - \\
\hline
\end{tabular}

${ }^{* *}$ Correlation is significant at the 0.001 level. 
SEM using AMOS v18 was employed to test the null hypothesis, where all estimates equaled zero between the latent unobserved factors, as shown in Figure 3. Those hypotheses test the direct and indirect interrelationships between system quality with intention to use/use and user satisfaction.

Table 4 shows the selected output from AMOS v18, representing the hypotheses, direct, indirect effect, and the squared multiple correlations (SMC). As shown in Table 4, all the hypothesized relationships were positive and significantly different from zero, thus rejecting the null hypotheses (estimate equals zero), and confirming the positive relationships between the research hypotheses. More specifically, the results of the SEM showed positive regression weights and significant $P$-value for the effect of system qualities on other constructs as follows: (H1a) Management-based trust $(\beta=0.51$, $P<0.001)$; (H1b) System-based trust $(\beta=0.39, P<0.001)$; and $(\mathrm{H} 1 \mathrm{c})$ Provider-based trust $(\beta=0.63$, $P<0.001)$.

Additionally, there were direct effects of Management-based trust on user satisfaction (H2a) ( $\beta=0.37, P<0.001)$; and (H2b) intention to use/use $(\beta=0.52, P<0.001)$. SEM results also showed a direct significant impact of System-based trust on user satisfaction $(\mathrm{H} 3 \mathrm{a})(\beta=0.51, P<0.001)$ and intention to use/use (H3b) $(\beta=0.30, P<0.001)$, and a direct significant impact of Provider-based trust on user satisfaction (H4a) $(\beta=0.32, P<0.001)$ and intention to use/use $(\mathrm{H} 4 \mathrm{~b})(\beta=0.29, P<0.001)$, and finally, a direct significant impact of user satisfaction on intention to use/ use (H5) $(\beta=0.60, P<0.001)$.

The results also showed that senior management, system-based, and provider-based trust completely mediate the relationship between system qualities and user satisfaction and intention to use/use (H6, H7), as the total indirect effect between system quality and user satisfaction (through senior management, system-based, and provider-based trust) was 0.53 . Similarly, the total indirect effect between system qualities and intention to use/use (through senior management-based trust, system-based trust, and provider-based trust) was 0.63, which supports hypotheses H6 and H7, as shown in Table 4 and Figure 2.

Finally, the predictive power results revealed that $\mathrm{R} 2$ values for the study of endogenous factors are as follows - management-based trust (0.26), system-based trust (0.15), provider-based trust $(0.40)$, intention to use/use (0.50), and user satisfaction (0.80).

\section{Discussion and Implications}

This study explores the mediating role of employees' trust in the successful adoption of tourism IS, within the public sector, and developing country contexts (the Egyptian tourism public sector). Following the recommendations of prior studies [24], trust has been studied based on a multiple-types approach, considering the employees' trust in IS, the provider of the IS, and the senior management. The findings confirmed that employees' trust completely mediates the effects of IS qualities (system, service, and information quality) on satisfaction and intention to use/use. The results suggested that, if employees perceived the IS as high-quality systems providing relevant and quality information, which are friendly and easy to use, and which provide reliable and responsive services, they would trust the systems and perceive IS providers and senior managers as trustworthy, competent, skilled, and able to make good decisions (ability), possessing positive intentions to provide support to employees (benevolence), and making good-faith agreements and fulfilling promises (integrity). Such trusting beliefs enable satisfaction and encourage employees' intention to better use IS, which in turn increases the success of the system.

Given the dearth of trust-related research in tourism IS adoption and developing context, this study provides theoretical implications for tourism, ISs, and the trust literature in several ways. First, the critical influence of information quality $[12,13,19]$, service quality $[40,45]$, and system quality $[14,46]$ on system-based trust and provider-based trust $[30,40]$ has only been studied in tourism e-commerce and mobile application adoption research from customer perspectives. For a further understanding of IS qualities' influence on trust, this study asserted prior results by/while examining different perspectives (employees' trust) and contexts (public tourism sector). The results contended that IS qualities directly influenced employees' trust, in the following descending order-trust in IS provider 
( $\beta=0.63, P<0.001)$, trust in senior management $(\beta=0.51, P<0.001)$, and system-based trust $(\beta=0.39$, $P<0.001)$. In addition, this research was the first-in tourism and IS studies-to examine and support the positive influence of IS qualities on management-based trust, which was found to be as important as provider-based and system-based trust. This finding enhances the understanding of tourism IS adoption and can also inform research that investigates antecedents of employees' trust in senior management (e.g., [64]).

Second, the results also show that perceived trust strongly predicts employees' satisfaction with and intention to use IS. Employees' trust in the qualities of IS were found to have a significant influence on their satisfaction (with the higher influential factor, $\beta=0.51, P<0.001$ ), which agrees with prior findings in e-tourism and other web-based IS research. For instance, Chung and Kwon [47] referred to satisfaction as a consequence of trust, while Abdal-Fadeel [6] stated that web-based tourism IS not perceived as trustworthy had lower user satisfaction levels, which subsequently hinders successful adoption. Furthermore, the results revealed the influence of management-based $(\beta=0.37, P<0.001)$ and provider-based ( $\beta=0.32, P<0.001)$ trust on employees' satisfaction. In relation, Chathoth et al. [34], who studied trust and satisfaction in hotels, found that employees' satisfaction could be improved by enhancing their perceptions of organizational trust. However, Chathoth et al.'s [34] study did not expose how such an influence would affect employee's performance or behavior.

Third, distinct from previous tourism and trust studies, which focused on the influence of customer trust on online IS usage intention [12-14,17], this study has instead investigated the effect of employees' trust on tourism IS adoption. The findings suggest that employees of the public tourism sector would choose to avoid using the adopted ISs if they had low trust in the ability, benevolence, and integrity of senior management, IS themselves, and providers, thus limiting the chances of IS success in tourism organizations. Also, these results contributed to advance the limited organizational IS studies which only explored the influence of system [20] and provider-based [26] trust on IS use by investigating the influence of trust in senior management on employees' intention to use/use IS. Even that, management-based trust, which was not examined in prior tourism or IS research, was found to have a greater impact on IS use $(\beta=0.52, P<0.001)$ compared to system $(\beta=0.30$, $P<0.001)$ and provider-based trust $(\beta=0.29, P<.001)$. These findings conform with some previous studies' results and contradict with others. For instance, they agree with Nwankpa and Roumani [21], who examined private-sector employees' perspective and considered trust as a key factor in using a system while they contradicted [31], who studied trust in a developing country context, as applied in this study. They examined trust in mobile-commerce services and found that provider-based trust did not influence customers' intention to use/use the system.

Fourth, while previous tourism studies have proposed trust as an antecedent of satisfaction [6,34] and intention to use/use [12-14,17], this study identified it as an influential mediating factor that connects system qualities to employees' satisfaction and intention to use/use tourism IS. In general, the mediating role of trust in the relationship between IS success factors received little attention in prior e-commerce and mobile application studies [19,30], and was widely neglected in tourism [14] and organizational IS research. Thus, the findings of this study add to the literature by establishing that in the public tourism sector IS adopted in Egypt (a developing country), trust (in IS, providers, and senior management) fully mediates IS success factors (Table 4). This corroborates the findings of prior studies on e-commerce and mobile IS, indicating that trust mediates the influence of information [19], system, and service quality [30] on satisfaction [19] and intention to use [30]. However, in e-commerce, Chuang and Fan [30] found that information quality has an insignificant impact on provider-based trust and-contrary to the findings of this study—on the intention to use/use.

To end, trust and IS are described as complex subjects that are affected by many contextual factors $[6,18]$. Thus, the contradictory results presented in prior studies about the influence of the relationships between trust and IS success factors can be attributed to investigating different types of trust (system, provider, co-worker, and institutional trust), units of analysis (e.g., public or private sectors), and different contexts (e-commerce or organizational-based IS), in addition to cultural and 
economic differences between the contexts of developed and developing countries. Further studies would need to explore such a difference and how it impacts on the relationship between trust and the successful adoption of tourism IS.

\section{Managerial Implications}

The results of this study are generalized to the Egyptian tourism public sector and can inspire organizations in other developing countries where usage of the adopted IS is optional, not mandatory. The results inform tourism senior managers and executives seeking to maximize IS benefits and potential, enabling them to consider what influences successful implementation. First, the results draw attention to the mediating influence of employees' trust on the successful adoption of IS and recognized IS's qualities as antecedents to employees' trust. Thus, guaranteeing high qualities of IS in terms of information (e.g., precise and needed information), system (e.g., user-friendly and ease of use), and service (e.g., reliability, assurance and responsiveness) should be a major consideration for senior managers of public tourism organizations. Also, high IS qualities were found to enhance the employee's perception of senior management as being competent and skilled (abilities and attributes), possessing positive intentions to provide support to employees (benevolence), and making good-faith agreements and fulfilling promises (integrity), which, in turn, increases satisfaction and effective usage. Therefore, it is critical for managers whose public organizations employ IS projects to focus on building a trusting environment with their employees to ultimately seize/empower success of their IS investment. Promoting trust among employees can also be developed through, for example, providing training courses at different stages of implementing the IS. This is to provide employees with the technical skills needed to work effectively with the system and further enhance communication and engagement with the provider. This would also contribute towards building employees' trust in senior managers as well as the system provider.

The current situation, dictated by the dire and far-reaching impact of COVID-19's unforeseen outbreak, has underpinned the idea that the adoption of IS could be a most convenient, if not unavoidable, step to be taken by public organizations in the tourism sector should they desire to cope with our rapidly changing world.

\section{Limitations and Future Research}

This study has limitations that future research can overcome for better understanding and richer insights into the subject. First, the generalizability of the results may be limited because data were collected from public tourism organizations in a single national context, Egypt. It would be useful to see if the results of this study are replicated in investigations of other nations and business settings.

Second, apart from IS qualities, other factors may also improve user satisfaction and intention to use/use, such as training [65] and subjective norms [66]. However, given the Ceteris Paribus assumption adopted in this study, all these other factors are held constant so that the effect of a single independent variable (IS qualities practices) on the dependent variable (user satisfaction and intention to use/use) could be isolated from the effects of other variables.

Third, we opted for quantitative data for this study. Qualitative methods can explore the richness of employees' experiences with organizational systems in-depth, and explore features that are not constrained to a defined list of factors. Using mixed methods could offer a fuller understanding of the impact employees' trust has on successful tourism IS adoption.

Another limitation is the cross-sectional sample design conducted in this study. In any model in which causality is assumed, longitudinal studies support stronger inferences [67]. Accordingly, while causal relations can be obtained, they cannot be closely confirmed in cross-sectional studies. One of the main requirements of showing causality between variables is temporal ordering, which can only be recognized by a longitudinal study (i.e., cause must be exposed to unambiguously precede an effect) [68]. Thus, the mediating role of employees' trust in tourism IS success is preferred to be tested in a longitudinal study. 
To end, the proper understanding of employees' trust influence on tourism IS success still needs more insights from diverse settings. This paper studied system-based, provider-based, and management-based trust concerning employees' experiences of IS in a tourism public sector context. Further studies can broaden the perspective by investigating other trust types at different stages of system implementation (initial trust and trust after system usage). This also needs to be carried out considering mandatory and optional usage, private and public tourism contexts, and the factors of developed and developing countries. Further studies could also look at ways to initiate and maintain trust in management, providers, and the IS themselves, to improve employees' satisfaction and usage of tourism IS's, and thus their success. The current study referred to the significance of IS adoption to the development of sustainable competitiveness. Further research could look into the influence of employees' trust in sustainable development and relate that with IS success implementation.

Author Contributions: Conceptualization and research framework: M.G.; methodology: I.E. and A.S.; software and formal analysis: I.E. and A.S.; data collection: A.S.; writing-original draft preparation: M.G., I.E. and A.S.; writing-review and editing: M.G., I.E. and A.S.; visualization: A.S.; Discussion and implications: M.G., I.E. and A.S. All authors have read and agreed to the published version of the manuscript.

Funding: This study received no external funding.

Conflicts of Interest: The authors declare no conflict of interest.

\section{Appendix A}

Table A1. Measurements of variables.

\begin{tabular}{|c|c|c|}
\hline Variables & Items & Supporting Literature \\
\hline \multirow{3}{*}{ Intention to use/use } & My frequency of using the system is high & \multirow{3}{*}{ Özkan et al. [69] and Rai et al. [70] } \\
\hline & 2. I depend on the system in performing my work & \\
\hline & 3. This system fully matches my original expectations & \\
\hline \multirow{3}{*}{ Satisfaction } & 1. I am satisfied with this system & \multirow{3}{*}{ Özkan et al. [69] and Rai et al. [70] } \\
\hline & 2. I recommend using the system in other governments & \\
\hline & 3. The system satisfies user requirements & \\
\hline \multirow{3}{*}{ System quality } & 1. The system is easy to use & \multirow{3}{*}{$\begin{array}{l}\text { DeLone and McLean [39] and } \\
\text { Özkan et al. [69] }\end{array}$} \\
\hline & 2. The system is user friendly & \\
\hline & 3. It's easy for me to become skillful at using the system & \\
\hline \multirow[b]{3}{*}{ Information quality } & 1. The system provides precise information & \multirow{3}{*}{ Rai et al. [70] } \\
\hline & 2. The system provides exactly the needed information & \\
\hline & $\begin{array}{l}\text { 3. The output options (print type, page sizes allowed for, etc } \\
\text {... ) are enough }\end{array}$ & \\
\hline \multirow{5}{*}{ Service quality } & $\begin{array}{l}\text { 1. The output information consistent and dependable } \\
\text { (reliability) }\end{array}$ & \multirow{5}{*}{$\begin{array}{l}\text { DeLone and McLean [39] and } \\
\text { Özkan et al. [69] }\end{array}$} \\
\hline & 2. The system has up to date software and hardware (tangibility) & \\
\hline & 3. The system gives prompt service to users (responsiveness). & \\
\hline & $\begin{array}{l}\text { 4. The system technical support teams have the knowledge to } \\
\text { do their job well (assurance) }\end{array}$ & \\
\hline & $\begin{array}{l}\text { 5. The system technical support teams have users' best interests } \\
\text { at heart (empathy of the personnel staff) }\end{array}$ & \\
\hline \multirow{3}{*}{ System-based trust } & 1. The system usually fulfills the commitments it assumes & \multirow{3}{*}{$\begin{array}{l}\text { After Koo and Wati [19], } \\
\text { Mayer et al. (1995) }\end{array}$} \\
\hline & 2. I can trust the system & \\
\hline & 3. I trust the information presented by the system & \\
\hline \multirow{5}{*}{ Management-based trust } & $\begin{array}{l}\text { 1. I can expect senior managers to treat me in a consistence and } \\
\text { predictable fashion (integrity) }\end{array}$ & \multirow{5}{*}{$\begin{array}{l}\text { After Mayer et al. [35] and } \\
\text { Söllner et al. [24] }\end{array}$} \\
\hline & $\begin{array}{l}\text { 2. I believe senior managers' motives and intentions to support } \\
\text { me are good (benevolence). }\end{array}$ & \\
\hline & $\begin{array}{l}\text { 3. I can count on actions/information provided by the senior } \\
\text { management (integrity) }\end{array}$ & \\
\hline & 4. Senior managers are competent and skilled managers (ability) & \\
\hline & 5. Senior managers take good decisions (ability) & \\
\hline \multirow{3}{*}{ Provider-based trust } & 1. The provider does a good job (ability) & \multirow{3}{*}{$\begin{array}{l}\text { After Mayer et al. [35] and } \\
\text { Söllner et al. [24] }\end{array}$} \\
\hline & 2. I can count on the statements of the provider (integrity) & \\
\hline & $\begin{array}{l}\text { 3. It is important for the provider that he can support me in } \\
\text { achieving my goals (benevolence) }\end{array}$ & \\
\hline
\end{tabular}




\section{References}

1. Standing, C.; Jackson, P. An approach to sustainability for information systems. J. Syst. Inf. Technol. 2007. [CrossRef]

2. Zeng, F.; Lee, S.H.N.; Lo, C.K.Y. The role of information systems in the sustainable development of enterprises: A systematic literature network analysis. Sustainability 2020, 12, 3337. [CrossRef]

3. Dwivedi, Y.; Wastell, D.; Laumer, S.; Henriksen, H.; Myers, M.; Bunker, D.; Elbanna, A.; Ravishankar, M.N.; Srivastava, S. Research on information systems failures and successes: Status update and future directions. Inf. Syst. Front. 2015, 17, 143-157. [CrossRef]

4. Gefen, D. E-commerce: The role of familiarity and trust. Omega Int. J. Manag. Sci. 2000, 28, 725-737. [CrossRef]

5. Petter, S.; DeLone, W.; McLean, E. Information systems success: The quest for the independent variables. J. Manag. Inf. Syst. 2013, 29, 7-62. [CrossRef]

6. Abdal-Fadeel, M. Destination Management Systems: Towards a Holistic Effectiveness Evaluation. Ph.D. Thesis, The University of Hull, Hull, UK, 2011. Available online: http://ethos.bl.uk/OrderDetails.do? uin=uk.bl.ethos.541576\#sthash.gcl1dGVT.dpuf (accessed on 7 May 2020).

7. Bliemel, M. A dynamic model for trust in e-business. In Proceedings of the 4th World Congress on the Management of Electronic Business, Hamilton, ON, Canada, 1-3 January 2003.

8. Molla, A.; Licker, P. E-commerce systems success: An attempt to extend and respecify the DeLone and McLean model of IS success. J. Electron. Commer. Res. 2001, 2, 131-141.

9. McKnight, D.H.; Choudhury, V.; Kacmar, C. Developing and validating trust measures for e-commerce: An integrative typology. Inf. Syst. Res. 2002, 11, 334-359. [CrossRef]

10. Öksüz, A.; Walter, N.; Distel, B.; Räckers, M.; Becker, J. Trust in the information systems discipline. In Trust and communication in a digitized world: Progress in Information Systems; Blöbaum, B., Ed.; Springer: Cham, Switzerland, 2016.

11. Söllner, M.; Benbasat, I.; Gefen, D.; Leimeister, J.; Pavlou, P. MIS Quarterly Research Curations. Available online: http://misq.org/research-curations (accessed on 7 May 2020).

12. Masri, N.W.; You, J.J.; Ruangkanjanases, A.; Chen, S.C.; Pan, C.I. Assessing the effects of information system quality and relationship quality on continuance intention in e-tourism. Int. J. Environ. Res. Public Health 2020, 17, 174. [CrossRef] [PubMed]

13. Ponte, E.B.; Carvajal-Trujill, E.; Escobar-Rodr, T. Influence of trust and perceived value on the intention to purchase travel online: integrating the effects of assurance on trust antecedents. Tour. Manag. 2015, 47, 286-302. [CrossRef]

14. Wang, L.; Law, R.; Guillet, B.D.; Hung, K.; Fong, D.K.C. Impact of hotel website quality on online booking intentions: eTrust as a mediator. Int. J. Hosp. Manag. 2015, 47, 108-115. [CrossRef]

15. Hew, J.-J.; Lee, V.-H.; Leong, L.-Y.; Hew, T.-S.; Ooi, K.-B. The dawning of mobile tourism: what contributes to its system success? Int. J. Mob. Commun. 2016, 14, 170-201. [CrossRef]

16. Wang, H.M.; Enkhbayar, G. Consumers Intention to use M-commerce in Tourism Industry. Int. J. Inf. Technol. Bus. Manag. 2015, 37, 35-49.

17. Filieri, R. Why do travelers trust tripadvisor? Antecedents of trust towards consumer-generated media and its influence on recommendation adoption and word of mouth. Tour. Manag. 2015, 51, 174-185. [CrossRef]

18. Cyr, D. Website design, trust and culture: An eight country investigation. Electron. Commer. Res. Appl. 2013, 12, 373-385. [CrossRef]

19. Koo, C.; Wati, Y. Toward an understanding of the mediating role of "trust" in mobile banking service: An empirical test of Indonesia case. J. Univers. Comput. Sci. 2010, 16, 1801-1824.

20. Thielsch, M.T.; Meeßen, S.M.; Hertel, G. Trust and distrust in information systems at the workplace. Peer] 2018, 6, e5483. [CrossRef] [PubMed]

21. Nwankpa, J.K.; Roumani, Y. The influence of organizational trust and organizational mindfulness on ERP systems usage. Commun. Assoc. Inf. Syst. 2014, 34, 85. [CrossRef]

22. Hassanein, K.; Head, M. The influence of product type on online trust. In Proceedings of the 17th Bled Electronic Commerce Conference, Bled, Slovenia, 21-23 June 2004.

23. Abdul-Rahman, A.; Hailes, S. Supporting trust in virtual communities. In Proceedings of the 33rd Hawaii International Conference on System Sciences (HICSS), Maui, HI, USA, 7 January 2000. 
24. Söllner, M.; Hoffmann, A.; Leimeister, J.M. Why different trust relationships matter for information systems users. Eur. J. Inf. Syst. 2016, 25, 274-287. [CrossRef]

25. Hung, W.H.; Ho, C.F.; Jou, J.J.; Kung, K.H. Relationship bonding for a better knowledge transfer climate: An ERP implementation research. Decis. Support Syst. 2012, 52, 406-414. [CrossRef]

26. Schniederjans, D.; Yadav, S. Successful ERP implementation: An integrative model. Bus. Process Manag. J. 2013, 19, 364-398. [CrossRef]

27. Schoorman, F.D.; Mayer, R.C.; Davis, J.H. An integrative model of organizational trust: Past, present, and future. Acad. Manag. Rev. 2007, 32, 344-354. [CrossRef]

28. Searle, R.; Weibel, A.; Den Hartog, D. Employee trust in organizational contexts. Int. Rev. Ind. Organ. Psychol. 2011, 26, 143-191.

29. Ayeh, J.K.; Au, N.; Law, R. Do we believe in TripAdvisor? Examining credibility perceptions and online travelers' attitude toward using user generated content. J. Travel Res. 2013, 52, 437-452. [CrossRef]

30. Chuang, H.M.; Fan, C.J. The mediating role of trust in the relationship between e-retailer quality and customer intention of online shopping. Afr. J. Bus. Manag. 2011, 5, 9522-9529.

31. Van Slyke, C.; Belanger, F.; Comunale, C.L. Factors influencing the adoption of web-based shopping: The impact of trust. Acm Sigmis Database 2004, 35, 32-49. [CrossRef]

32. Joubert, J.; Van Belle, J. The role of trust and risk in mobile commerce adoption within South Africa. Int. J. Bus. Humanit. Technol. 2013, 3, 27-38.

33. Ayyash, M.M.; Ahmad, K.; Singh, D.S.V. Investigating the effect of information systems factors on trust in e-government initiative adoption in Palestinian public sector. Res. J. Appl. Sci. Eng. Technol. 2013, 5, 3865-3875. [CrossRef]

34. Chathoth, P.K.; Mak, B.; Jauhari, V.; Manaktola, K. Employees' perceptions of organizational trust and service climate: A structural model combining their effects on employee satisfaction. J. Hosp. Tour. Res. 2007, 31, 338-357. [CrossRef]

35. Mayer, R.C.; Davis, J.H.; Schoorman, F.D. An integrative model of organizational trust. Acad. Manag. Rev. 1995, 20, 709-734. [CrossRef]

36. Gefen, D.; Benbasat, I.; Pavlou, P. A research agenda for trust in online environment. J. Manag. Inf. Syst. 2008, 24, 275-286. [CrossRef]

37. Heyns, M.; Rothmann, S. Dimensionality of trust: An analysis of the relations between propensity, trustworthiness and trust. Sa J. Ind. Psychol. 2015, 41. [CrossRef]

38. Holtgrave, M.; Nienaber, A.M.; Tzafrir, S.S.; Schewe, G. Cooperation in the Face of Conflict: Effects of Top Managers' Trust Beliefs in their Firms' Major Suppliers. Br. J. Manag. 2019, 31, 253-273. [CrossRef]

39. DeLone, W.H.; McLean, E.R. The DeLone and McLean model of information systems success: A ten-year update. J. Manag. Inf. Syst. 2003, 19, 9-30.

40. Brown, I.; Jayakody, R. B2C e-commerce success: A test and validation of a revised conceptual model. Electron. J. Inf. Syst. Eval. 2008, 11, 167-184.

41. Egdair, I.M.; Rajemi, M.F.; Nadarajan, S. Technology factors, ERP system and organization performance in developing countries. Int. J. Supply Chain Manag. 2015, 4, 82-89.

42. Rizal, H.; Yussof, S.; Amin, H.; Chen-Jung, K. EWOM towards homestays lodging: extending the information system success model. J. Hosp. Tour. Technol. 2018, 9, 94-108. [CrossRef]

43. Chung, N.; Lee, H.; Lee, S.J.; Koo, C. The influence of tourism website on tourists' behavior to determine destination selection: A case study of creative economy in Korea. Technol. Forecast. Soc. Chang. 2015, 96, 130-143. [CrossRef]

44. Filieri, R.; McLeay, F.; Tsui, B. Antecedents of Travellers' Satisfaction and Purchase Intention from Social Commerce Websites. In Information and Communication Technologies in Tourism 2017; Springer: Cham, Switzerland, 2017.

45. Keen, P.; Ballance, G.; Chan, S.; Schrump, S. Electronic Commerce Relationships: Trust by Design; Prentice Hall PTR: Upper Saddle River, NJ, USA, 2000.

46. Lee, K.C.; Chung, N. Understanding factors affecting trust in and satisfaction with mobile banking in Korea: A modified DeLone and McLean's model perspective. Interact. Comput. 2009, 21, 385-392. [CrossRef]

47. Chung, N.; Kwon, S.J. Effect of trust level on mobile banking satisfaction: A multi-group analysis of information system success instruments. Behav. Inf. Technol. 2009, 28, 549-562. [CrossRef]

48. Huntington, P.; Nicholas, D.; Gunter, B.; Russell, C.; Withey, R.; Palydoratou, P. Consumer trust in health information on the web. Aslib Proc. 2004, 56, 373-382. [CrossRef] 
49. Almajali, D.; Masa'deh, R.; Tarhini, A. Antecedents of ERP systems implementation success: A study on Jordanian healthcare sector. J. Enterp. Inf. Manag. 2016, 29, 549-565. [CrossRef]

50. Zaied, A.N.H. An integrated success model for evaluating information system in public sectors. J. Emerg. Trends Comput. Inf. Sci. 2012, 3, 814-825.

51. Alhabash, S.; Brooks, B.; Jiang, M.; Rifon, N.; La Rose, R.; Cotton, S. Is it institutional or system-based trust? Mediating the effect of generational cohort membership on online banking intentions. In Proceedings of the iConference 2015 Summary, Oakland, CA, USA, 24-27 March 2015.

52. DeLone, H.; McLean, E. Measuring e-commerce success: Applying the DeLone and McLean information systems success model. Int. J. Electron. Commer. 2004, 9, 31-47. [CrossRef]

53. Stevens, J.P. Applied Multivariate Statistics for the Social Sciences, 5th ed.; Routledge, Taylor \& Francis Group: London, UK, 2009.

54. Tabachnick, B.; Fidell, L. Using Multivariate Statistics, 5th ed.; Pearson Education: New York, NY, USA, 2007.

55. Byrne, B. Structural Equation Modeling with AMOS: Basic Concepts, Applications, and Programming, 2nd ed.; Routlege: Abingdon, UK, 2010.

56. Hair, J.; Black, W.; Babin, B.; Anderson, R. Multivariate Data Analysis, 8th ed.; Pearson Education: New Jersey, NJ, USA, 2014.

57. Nunnally, J.C. Psychometric Theory; McGraw Hill: New York, NY, USA, 2008.

58. Boomsma, A. The robustness of LISREL against small sample sizes in factor analysis models. Available online: http://citeseerx.ist.psu.edu/viewdoc/download?doi=10.1.1.11.684\&rep=rep1\&type=pdf (accessed on 7 May 2020).

59. Lindell, M.K.; Whitney, D.J. Accounting for common method variance in cross-sectional research designs. J. Appl. Psychol. 2001, 86, 114. [CrossRef]

60. Podsakoff, P.M.; MacKenzie, S.B.; Jeong-Yeon, L.; Podsakoff, N.P. Common method biases in behavioral research: A critical review of the literature and recommended remedies. J. Appl. Psychol. 2003, 88, 879-903. [CrossRef] [PubMed]

61. Salancik, G.R.; Pfeffer, J. An examination of need-satisfaction models of job attitudes. Adm. Sci. Q. 1977, 22, 427-456. [CrossRef]

62. Bagozzi, R.P.; Heatherton, T.F. A general approach to representing multifaceted personality constructs: Application to state self-esteem. Struct. Equ. Modeling: A Multidiscip. J. 1994, 1, 35-67. [CrossRef]

63. Kline, R. Principles and Practice of Structural Equation Modelling; Guilford Press: New York, NY, USA, 2015.

64. Liu, J.; Siu, O.L.; Shi, K. Transformational leadership and employee well-being: The mediating role of trust in the leader and self-efficacy. Appl. Psychol. 2010, 59, 454-479. [CrossRef]

65. Dezdar, S.; Ainin, S. The influence of organizational factors on successful ERP implementation. Manag. Decis. 2011, 49, 911-926. [CrossRef]

66. Chen, S.C.; Yen, D.C.; Hwang, M.I. Factors influencing the continuance intention to the usage of Web 2.0: An empirical study. Comput. Hum. Behav. 2012, 28, 933-941. [CrossRef]

67. Morgan, R.M.; Hunt, S.D. The commitment-trust theory of relationship marketing. J. Mark. 1994, 58, $20-28$. [CrossRef]

68. Bullock, H.E.; Harlow, L.L.; Mulaik, S.A. Causation issues in structural equation modeling research. Struct. Equ. Modeling 1994, 1, 253-267. [CrossRef]

69. Özkan, S.; Çakır, M.; Bilgen, S. A maturity based qualitative information systems effectiveness evaluation of a public organization in Turkey. J. Cases Inf. Technol. 2008, 10, 58-71. [CrossRef]

70. Rai, A.; Lang, S.; Welker, R. Assessing the validity of IS success models: An empirical test and theoretical analysis. Inf. Syst. Res. 2002, 13, 50-69. [CrossRef]

(C) 2020 by the authors. Licensee MDPI, Basel, Switzerland. This article is an open access article distributed under the terms and conditions of the Creative Commons Attribution (CC BY) license (http://creativecommons.org/licenses/by/4.0/). 